\title{
Ebola Virus Disease Surveillance and Response Preparedness in Northern Ghana
}

\author{
Martin N. Adokiya*1 and John Koku Awoonor-Williams ${ }^{2,3}$ \\ ${ }^{1}$ Department of Community Health, University for Development Studies, Tamale, Ghana; ${ }^{2}$ Regional Health Directorate, Ghana Health \\ Service, Upper East Region, Bolgatanga, Ghana; ${ }^{3}$ Swiss Tropical and Public Health Institute, Switzerland, and University of Basel, \\ Basel, Switzerland
}

\section{Objective}

The objective of this study was to assess the EVD surveillance and response preparedness among frontline health workers in northern Ghana.

\section{Introduction}

The recent Ebola outbreak has been described as unprecedented and its public health impact in terms of morbidity, mortality and coverage has been far greater than previously experienced [1-3]. This outbreak has revealed many weaknesses and inadequacies for disease surveillance and response systems in Africa due to underqualified staff, cultural beliefs and sometimes, lack of trust for formal health care sector performance [4-6]. Since 2014, Ghana had high risk of seeing EVD cases [2].

\section{Methods}

Ghana is situated in West Africa and bordered by Ivory Coast to the west, Burkina Faso to the north, Togo to the east, and the Atlantic Ocean to the south. This was an observational study conducted among 47 frontline health workers in all the thirteen districts of the Upper East Region representing public, mission and private health services. A semi-structured questionnaire with focus on core and support functions (e.g. detection, confirmation etc.) was administered to the informants. In addition, 34 weekly IDSR reports (August 2014 to March 2015) were collated from each district.

\section{Results}

Clinically diagnosed data revealed that 4 out of the 13 districts reported 9 EVD cases in 2014. Out of the 9 suspected cases, 8 of them died and the cause of death was unexplained. Bawku Municipal was the only district that reported a suspected case in 2015. All the ten suspected cases reported, none was confirmed (i.e. positive for the virus antigen).

The 47 key informants were (medical officers, district directors, disease control officers and laboratory officers). They had knowledge on EVD surveillance as well as the reporting of data. However, there were some challenges affecting surveillance and response preparedness such as delay in reporting, low quality personal protective equipment (e.g. gloves, aprons, infra-red thermometers etc.), inadequate staff and lack of laboratory capacity to test samples at the district or regional levels. Over $80 \%(38 / 47)$ of the informants were not satisfied with EVD surveillance. The reasons cited include lack of infra-red thermometers, ineffective screening, and lack of isolation centres.

\section{Conclusions}

EVD surveillance is still insufficient, particularly the inadequate PPEs and lack of laboratory capacity to test suspected cases as well as local burial practices. The Ebola epidemic is a wake-up call for early case detection and response preparedness. This topic remains a neglected and deprived public health issue in SSA. Thus, disease surveillance and prevention activities are urgently needed in the health system.
Key words: Disease surveillance, core and support functions, health information system, Ghana

\section{Keywords}

Disease surveillance; core and support functions; health information system; Ghana

\section{Acknowledgments}

The authors acknowledge the assistance of the staff of Ghana Health Service.

\section{References}

1. Issah K, Nartey K, Amoah R, Bachan EG, Aleeba J, Yeetey E, Letsa $\mathrm{T}$ : Assessment of the usefulness of integrated disease surveillance and response on suspected ebola cases in the Brong Ahafo Region, Ghana. Infectious diseases of poverty 2015, 4:17.

2. Gomes MF, Pastore YPA, Rossi L, Chao D, Longini I, Halloran ME, Vespignani A: Assessing the international spreading risk associated with the 2014 west african ebola outbreak. PLOS Curr 2014, 6.

3. Alexander KA, Sanderson CE, Marathe M, Lewis BL, Rivers CM, Shaman J, Drake JM, Lofgren E, Dato VM, Eisenberg MC et al: What Factors Might Have Led to the Emergence of Ebola in West Africa? PLoS neglected tropical diseases 2015, 9(6):e0003652.

4. Adokiya MN, Awoonor-Williams JK, Beiersmann C, Muller O: The integrated disease surveillance and response system in northern Ghana: challenges to the core and support functions. $B M C$ health services research 2015, 15(1):288.

5. HMN, WHO: Country health information systems: a review of the current situation and trends. WHO Geneva, In.; 2011.

6. Adokiya MN, Awoonor-Williams JK, Barau IY, Beiersmann C, Mueller $O$ : Evaluation of the integrated disease surveillance and response system for infectious diseases control in northern Ghana. $B M C$ public health 2015, 15:75.

\section{*Martin N. Adokiya}

E-mail: nyaaba1979@yahoo.com 